\title{
Roles of $\mathrm{K}^{+}$and $\mathrm{Na}^{+}$in $\mathrm{pH}$ homeostasis and growth of the marine bacterium Vibrio alginolyticus
}

\author{
Tatsunosuke Nakamura, ${ }^{*}$ Satoko KaWaSaki $\dagger$ and Tsutomu Unemoto \\ Laboratory of Membrane Biochemistry, Faculty of Pharmaceutical Sciences, Chiba University, 1-33 Yayoi-cho, \\ Chiba 260, Japan
}

(Received 21 October 1991; revised 12 February 1992; accepted 17 February 1992)

\begin{abstract}
The marine bacterium Vibrio alginolyticus, containing $470 \mathrm{mM}-\mathrm{K}^{+}$and $70 \mathrm{mM}-\mathrm{Na}^{+}$inside its cells, was able to regulate the cytoplasmic $\mathrm{pH}\left(\mathrm{pH}_{\mathrm{in}}\right)$ in the narrow range 7.6-7.8 over the external $\mathrm{pH}\left(\mathrm{pH}_{\mathrm{out}}\right)$ range 6.0-9.0 in the presence of $400 \mathrm{mM}-\mathrm{Na}^{+}$and $10 \mathrm{mM}-\mathrm{K}^{+}$. In the absence of external $\mathrm{K}^{+}$, however, $\mathrm{pH}_{\mathrm{in}}$ was regulated only at alkaline $\mathrm{pH}_{\text {out }}$ values above 7.6. When the cells were incubated in the presence of unusually high $\mathrm{K}^{+}(400 \mathrm{mM})$ and $4 \mathrm{mM} \mathrm{Na}^{+}$, the $\mathrm{pH}_{\mathrm{in}}$ was regulated only at acidic $\mathrm{pH}_{\text {out }}$ values below 7.6. These results could be explained by postulating a $\mathrm{K}^{+} / \mathrm{H}^{+}$antiporter as the regulator of $\mathrm{pH}_{\text {in }}$ over the $\mathrm{pH}_{\text {out }}$ range 6.0-9.0. When $\mathrm{Na}^{+}$-loaded/K+depleted cells were incubated in $400 \mathrm{mM}-\mathrm{Na}^{+}$in the absence of $\mathrm{K}^{+}$, an inside acidic $\Delta \mathrm{pH}$ was generated at $\mathrm{pH}_{\text {out }}$ values above 7.0. After addition of diethanolamine the inside acidic $\Delta \mathrm{pH}$ collapsed transiently and then returned to the original value concomitant with the extrusion of $\mathrm{Na}^{+}$, suggesting the participation of a $\mathrm{Na}^{+} / \mathrm{H}^{+}$antiporter for the generation of an inside acidic $\Delta p H$. In the presence of $400 \mathrm{mM}-\mathrm{K}^{+}$, at least $5 \mathrm{mM}-\mathrm{Na}^{+}$was required to support cell growth at $\mathrm{pH}_{\text {out }}$ below 7.5. An increase in $\mathrm{Na}^{+}$concentration allowed the cells to grow at a more alkaline $\mathrm{pH}_{\text {our }}$ Furthermore, cells containing more $\mathrm{Na}^{+}$inside could more easily adapt to grow at alkaline $\mathrm{pH}_{\text {out }}$. These results indicated the importance of $\mathrm{Na}^{+}$in acidification of the cell interior via a Na $\mathbf{N}^{+} / \mathrm{H}^{+}$antiporter in order to support cell growth at alkaline $\mathrm{pH}_{\text {out }}$ under conditions where the activity of a $\mathrm{K}^{+} / \mathrm{H}^{+}$antiporter is marginal.
\end{abstract}

\section{Introduction}

Bacterial celis have the capacity to regulate cytoplasmic $\mathrm{pH}\left(\mathrm{pH}_{\mathrm{in}}\right)$ at around neutrality regardless of their external $\mathrm{pH}\left(\mathrm{pH}_{\text {out }}\right)\left(\right.$ Booth, 1985). For example, the $\mathrm{pH}_{\text {in }}$ of Vibrio alginolyticus (Nakamura et al., 1984) and Escherichia coli (Slonczewski et al., 1981) is regulated at about 7.6-7.8 over the $\mathrm{pH}_{\text {out }}$ range 6.0-9.0. At $\mathrm{pH}_{\text {out }}$ values below 7.6 the generation of an inside alkaline $\Delta \mathrm{pH}$ is necessary for the regulation of $\mathrm{pH}_{\mathrm{in}}$. Since the $\mathrm{pH}_{\mathrm{in}}$ under an acidic $\mathrm{pH}_{\text {out }}$ condition is regulated only in the presence of $\mathrm{K}^{+}$, the uptake of $\mathrm{K}^{+}$is considered to help in the generation of an alkaline $\mathrm{pH}_{\text {in }}$ (Tokuda et al., 1981; Kroll \& Booth, 1983). However, it is not clear how the magnitude of $\Delta \mathrm{pH}$ is controlled depending on $\mathrm{pH}_{\text {out }}$.

* Author for correspondence. Tel. 472511111 ext. 2737; fax 47255 1574.

$\dagger$ Present address: Institute of Applied Microbiology, University of Tokyo, Japan.

Abbreviations: $\Delta \mathrm{P}$, protonmotive force; $\Delta \mathrm{pH}$, chemical gradient of $\mathrm{H}^{+} ; \Delta \mathrm{pK}$, chemical gradient of $\mathrm{K}^{+} ; \Delta \mathrm{pNa}$, chemical gradient of $\mathrm{Na}^{+}$; $\mathrm{pH}_{\mathrm{in}}$, internal $\mathrm{pH} ; \mathrm{pH}_{\text {out }}$, external $\mathrm{pH}$.
At $\mathrm{pH}_{\text {out }}$ values above 7.6, the generation of an inside acidic $\Delta \mathrm{pH}$ is necessary and $\mathrm{Na}^{+} / \mathrm{H}^{+}$and $\mathrm{K}^{+} / \mathrm{H}^{+}$ antiporters were implicated to function in achieving this (Brey et al., 1980). In alkalophilic bacteria, it became apparent that a $\mathrm{Na}^{+} / \mathrm{H}^{+}$antiporter acidifies $\mathrm{pH}_{\text {in }}$, cooperating with the $\mathrm{H}^{+}$-extruding respiratory chain (Mandel et al., 1980; Garcia et al., 1983). Mutants of $E$. coli defective in the $\mathrm{Na}^{+} / \mathrm{H}^{+}$antiporter grow poorly in alkaline media (Ishikawa et al., 1987; Padan et al., 1989) and the antiporter was shown to be required for growth of $E$. coli under alkaline $\mathrm{pH}_{\text {out }}$ (McMorrow et al., 1989). $\mathrm{Na}^{+} / \mathrm{H}^{+}$antiporter genes (nhaA) of $E$. coli (Niiya et al., 1982; Goldberg et al., 1987; Karpel et al., 1988; Padan et al., 1989) and Bacillus firmus (Ivey et al., 1991) have been cloned and sequenced. The $E$. coli NhaA protein has been purified and reconstituted in proteoliposomes and shown to function as a $\mathrm{Na}^{+} / \mathrm{H}^{+}$antiporter (Taglicht et al., 1991). However, it is uncertain whether this antiporter functions as a regulator of $\mathrm{pH}_{\mathrm{in}}$.

Although the $\mathrm{pH}_{\text {in }}$ of $V$. alginolyticus was acidified by $\mathrm{Na}^{+} / \mathrm{H}^{+}$antiporter activity at alkaline $\mathrm{pH}_{\text {out }}$, the $\mathrm{pH}_{\text {in }}$ was not regulated at a constant value in the absence of $\mathrm{K}^{+}$(Nakamura et al., 1984). Since the $\mathrm{K}^{+} / \mathrm{H}^{+}$antiporter 
of this organism is strongly dependent on the $\mathrm{pH}_{\mathrm{in}}$ and only active at $\mathrm{pH}_{\text {in }}$ values above $7 \cdot 6$, we proposed that the $\mathrm{K}^{+} / \mathrm{H}^{+}$antiporter functions as a regulator of $\mathrm{pH}_{\text {in }}$ at alkaline and acidic $\mathrm{pH}_{\text {out }}$ (Nakamura et al., 1984). To test this hypothesis, we examined the effects of $\mathrm{K}^{+}$and $\mathrm{Na}^{+}$ on $\mathrm{pH}$ homeostasis and the role of $\mathrm{Na}^{+}$for growth of $V$. alginolyticus at alkaline $\mathrm{pH}_{\text {out }}$.

\section{Methods}

Preparation of normal and $\mathrm{Na}^{+}$-loaded cells. $\mathrm{V}$. alginolyticus strain 138-2 was grown aerobically at $37^{\circ} \mathrm{C}$ in a synthetic medium containing $0.3 \mathrm{M}-\mathrm{NaCl}, 10 \mathrm{~mm}-\mathrm{KCl}, 2 \mathrm{~mm}-\mathrm{K}_{2} \mathrm{HPO}_{4}, 15 \mathrm{~mm}-\left(\mathrm{NH}_{4}\right)_{2} \mathrm{SO}_{4}, 10 \mu \mathrm{M}-$ $\mathrm{FeSO}_{4}, 5 \mathrm{~mm}-\mathrm{MgSO}_{4}, 1 \%$ (w/v) glycerol, $50 \mathrm{~mm}-\mathrm{Tris} / \mathrm{HCl}$ (pH 7.5). The cells were harvested in the exponential phase of growth and then washed with $0.4 \mathrm{M}-\mathrm{NaCl}$ by centrifugation. These cells contained $470 \mathrm{mM}-\mathrm{K}^{+}$and $70 \mathrm{mM}-\mathrm{Na}^{+}$and are referred to as normal cells. $\mathrm{Na}^{+}$ loaded/ $\mathbf{K}^{+}$-depleted cells were prepared using diethanolamine treatment as previously described (Nakamura et al., 1982). These cells contained about $400 \mathrm{~mm}-\mathrm{Na}^{+}$and less than $1 \mathrm{mM}-\mathrm{K}^{+}$.

Growth conditions. Cells were grown aerobically in a Monod-tube at $37^{\circ} \mathrm{C}$ and growth was monitored by measuring the optical density (OD) at $600 \mathrm{~nm}$ in a Perkin-Elmer model 35 spectrophotometer. The culture doubling time was calculated from the linear part of the exponential growth curve. For measurement of cell growth at alkaline $\mathrm{pH}_{\text {out }}$ in the presence of $0.5 \mathrm{M}-\mathrm{K}^{+}$(see Fig. 4), the cells were first cultured in a complex medium containing $0.5 \%(w / v)$ yeast extract and $0.5 \%(w / v)$ polypeptone, supplemented with $0.4 \%(\mathrm{w} / \mathrm{v}) \mathrm{K}_{2} \mathrm{HPO}_{4}$ and $0.5 \mathrm{M}-\mathrm{NaCl}$ (pH 7.4). When the culture density reached an $\mathrm{OD}$ at $600 \mathrm{~nm}$ of $0 \cdot 4$, a $1 / 50$ vol. of the culture was inoculated into fresh complex medium of specific $\mathrm{pH}$, supplemented with $0.5 \mathrm{M}-\mathrm{KCl}$ and buffer. Complex medium of appropriate $\mathrm{pH}$ was prepared by mixing a volume of complex medium containing $50 \mathrm{~mm}$-HEPES, $10 \mathrm{~mm}-\mathrm{KOH}$ (pH 6.6) with a volume of complex medium containing $50 \mathrm{~mm}$-Tris, $25 \mathrm{mM}$ CHES, 10 mM-KOH (pH 9.3). Since the complex medium contains about $5 \mathrm{mM}-\mathrm{Na}^{+}$, and $10 \mathrm{mM}-\mathrm{Na}^{+}$is carried over from the preculture, the concentration of $\mathrm{Na}^{+}$in the growth medium was about $15 \mathrm{mM}$. Taking this into consideration, further $\mathrm{Na}^{+}$was added as required. To adjust the $\mathrm{Na}^{+}$concentration to $5 \mathrm{mM}$ in the experiments depicted in Fig. 4, the cells were first cultured in the synthetic medium described above except that the salts were replaced with $0.5 \mathrm{M}-\mathrm{KCl}$ and $5 \mathrm{mM}-$ $\mathrm{NaCl}$ and the $\mathrm{pH}$ was adjusted to 7.0.

To prepare cells containing high or low internal $\mathrm{Na}^{+}$(see Fig. 5), the cells were first cultured in complex medium containing $56 \mathrm{mM}-\mathrm{MES}$, $10 \mathrm{mM}$-Tris and $15 \mathrm{mM}-\mathrm{KOH}$ (pH 6.8) and supplemented with either $0.4 \mathrm{M}-\mathrm{NaCl}$ or $0.4 \mathrm{M}-\mathrm{KCl}$. The former cells contained $70 \mathrm{mM}-\mathrm{Na}^{+}$and the latter less than $5 \mathrm{~mm}-\mathrm{Na}^{+}$. The culture was then diluted 8-fold with complex medium containing $0.4 \mathrm{M}-\mathrm{KCl}, 25 \mathrm{~mm}$-TAPS, $50 \mathrm{~mm}$-Tris, $15 \mathrm{mM}-\mathrm{KOH}$ (pH 8.8). The final $\mathrm{Na}^{+}$concentration in the growth medium was adjusted to $55 \mathrm{~mm}$.

Measurement of internal $\mathrm{pH}$, and internal $\mathrm{Na}^{+}$and $\mathrm{K}^{+}$concentrations. The inside alkaline or acidic $\Delta \mathrm{pH}$ was determined from the distribution of either $\left[{ }^{14} \mathrm{C}\right.$ )acetylsalicylic acid (New England Nuclear) or di $\left[{ }^{14} \mathrm{C}\right]-$ methylamine (Amersham) as described previously (Nakamura et al., 1984). Intracellular $\mathrm{Na}^{+}$and $\mathrm{K}^{+}$concentrations were determined by the filtration method and flame photometry, also as described previously (Nakamura et al., 1982).

Protein-assay. Protein concentration was determined by the Lowry method with bovine serum albumin as standard.

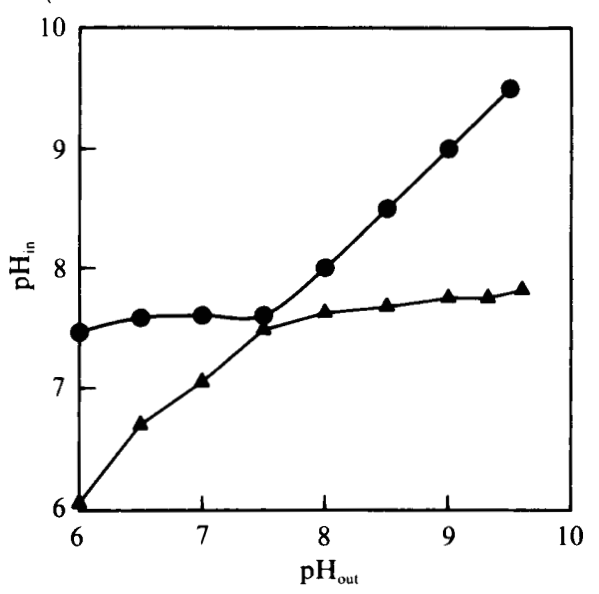

Fig. 1. Effects of $\mathrm{K}^{+}$and $\mathrm{Na}^{+}$on regulation of $\mathrm{pH}_{\text {in }}$ at various $\mathrm{pH}_{\text {out }}$ values. Normal cells of $V$. alginolyticus containing $470 \mathrm{~mm}-\mathrm{K}^{+}$and $70 \mathrm{mM}-\mathrm{Na}^{+}$were incubated in $\mathrm{K}^{+}$-medium $(O)$ or $\mathrm{Na}^{+}$-medium (A) for $6-8 \mathrm{~min}$ at $25^{\circ} \mathrm{C}$ and then the $\mathrm{pH}_{\mathrm{in}}$ at the respective $\mathrm{pH}_{\text {out }}$ was determined as described in Methods. The $\mathrm{K}^{+}$-medium contained $0.3 \mathrm{M}$ $\mathrm{KCl}, 0.1 \mathrm{M}$-potassium phosphate $(\mathrm{pH} \mathrm{6.0-7.7)}$ or $0.4 \mathrm{M}-\mathrm{KCl}, 50 \mathrm{mM}$ Tris/ $\mathrm{HCl}\left(\mathrm{pH} \mathrm{8.0-9 \cdot 0)}\right.$. The $\mathrm{Na}^{+}$-medium was prepared by replacing all of the $\mathrm{K}^{+}$in the above medium with $\mathrm{Na}^{+}$.

\section{Results}

\section{Effects of $\mathrm{K}^{+}$and $\mathrm{Na}^{+}$on the regulation of $\mathrm{pH}_{\text {in }}$}

When normal cells of $V$. alginolyticus were incubated in a medium containing $400 \mathrm{mM}-\mathrm{Na}^{+}$and $10 \mathrm{mM}-\mathrm{K}^{+}$, the $\mathrm{pH}_{\text {in }}$ was regulated within $7 \cdot 6-7 \cdot 8$ over the $\mathrm{pH}_{\text {out }}$ range 6.0-9.0 (Nakamura et al., 1984). Since an outwardly directed $\mathrm{K}^{+}$chemical gradient $(\Delta \mathrm{pK})$ was required for the regulation of $\mathrm{pH}_{\text {in }}$ at $\mathrm{pH}_{\text {out }}$ above 7.6, the normal cells were incubated in a medium containing $400 \mathrm{~mm}-\mathrm{K}^{+}$to minimize the magnitude of $\Delta \mathrm{pK}$. As shown in Fig. 1, the inside acidic $\Delta \mathrm{pH}$ was not generated at $\mathrm{pH}_{\text {out }}$ values above $7 \cdot 6$, but the $\mathrm{pH}_{\text {in }}$ was regulated at $\mathrm{pH}_{\text {out }}$ values below 7.6. The $\mathrm{Na}^{+}$-loaded/ $\mathrm{K}^{+}$-depleted cells gave the same results (data not shown).

Conversely, when normal cells were incubated in a medium containing $400 \mathrm{mM}-\mathrm{Na}^{+}$in the absence of $\mathrm{K}^{+}$, the $\mathrm{pH}_{\text {in }}$ was regulated only at alkaline $\mathrm{pH}_{\text {out }}$ and an inside alkaline $\Delta \mathrm{pH}$ was not generated at acidic $\mathrm{pH}_{\text {out }}$ (Fig. 1). Although the cells retained about $470 \mathrm{~mm}-\mathrm{K}^{+}$ and a large $\Delta \mathrm{pK}$ was maintained under these conditions, the $\mathrm{pH}_{\mathrm{in}}$ was not regulated at acidic $\mathrm{pH}_{\text {out }}$. The addition of more than $1 \mathrm{mM}-\mathrm{K}^{+}$was necessary for the regulation of $\mathrm{pH}_{\mathrm{in}}$. These results clearly indicated that for $\mathrm{pH}$ homeostasis the presence of $\Delta \mathrm{pK}$ is essential at alkaline, but not acidic, $\mathrm{pH}_{\text {out }}$ values and that the presence of $\mathrm{K}^{+}$ in the external medium is essential at acidic, but not alkaline, $\mathrm{pH}_{\text {out }}$ values. The requirement for external $\mathrm{K}^{+}$ in regulation of $\mathrm{pH}_{\mathrm{in}}$ at acidic $\mathrm{pH}_{\text {out }}$ suggested that 


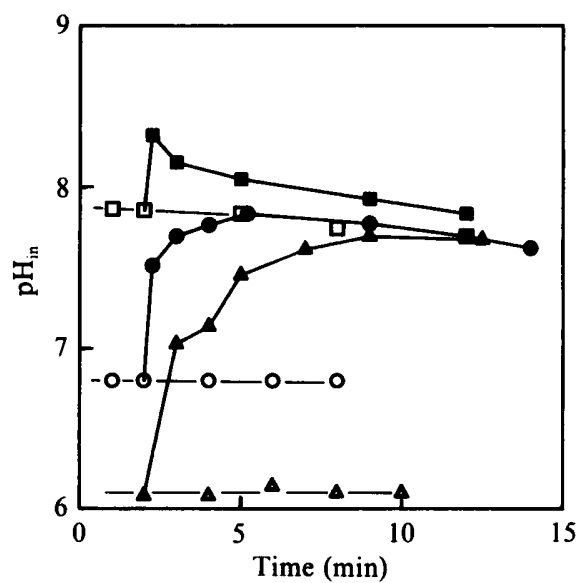

Fig. 2. Time course of changes in $\mathrm{pH}_{\text {in }}$ after addition of $\mathrm{KCl}$ at different $\mathrm{pH}_{\text {out }}$ values. $\mathrm{Na}^{+}-$loaded cells were suspended in $0.3 \mathrm{M}-\mathrm{NaCl}$, $20 \mathrm{mM}$-glycerol and $0.1 \mathrm{M}$-sodium phosphate at pH 6.1 $(\triangle)$, or $6.8(\mathrm{O})$ or in $0.4 \mathrm{M}-\mathrm{NaCl}$ and $50 \mathrm{~mm}$-Tricine $/ \mathrm{NaOH}$ at pH 9.0 ( $\square$ ). After $2 \mathrm{~min}$ incubation, $10 \mathrm{mM}-\mathrm{KCl}$ was added (filled symbols) and the $\mathrm{pH}_{\text {in }}$ was then determined.

alkalinization of the cytoplasm induced by the $\mathrm{K}^{+}$uptake is a prerequisite for $\mathrm{pH}$ homeostasis.

As shown previously (Nakamura et al., 1984), $\mathrm{Na}^{+}-$ loaded $/ \mathrm{K}^{+}$-depleted cells incubated in the absence of $\mathrm{K}^{+}$ generate an inside acidic $\Delta \mathrm{pH}$ at $\mathrm{pH}_{\text {out }}$ values above $7 \cdot 0$, but the addition of $10 \mathrm{~mm}-\mathrm{K}^{+}$is necessary to maintain a constant $\mathrm{pH}_{\text {in }}$. To examine the effect of $\mathrm{K}^{+}$uptake on regulation of $\mathrm{pH}_{\mathrm{in}}$, time courses of changes in $\mathrm{pH}_{\mathrm{in}}$ after addition of $\mathrm{K}^{+}$were measured. The $\mathrm{pH}_{\text {in }}$ of the $\mathrm{Na}^{+}-$ loaded cells suspended in medium of $\mathrm{pH}_{\text {out }} 6.1$ and 6.8 was the same as the respective $\mathrm{pH}_{\text {out }}$ (Fig. 2). Within 2 min of the addition of $10 \mathrm{~mm}-\mathrm{K}^{+}$the $\mathrm{pH}_{\text {in }}$ was alkalinized concomitant with $\mathrm{K}^{+}$uptake and was regulated at about $\mathrm{pH} 7.6$ within $10 \mathrm{~min}$. At a $\mathrm{pH}_{\text {out }}$ of 6.8 , the $\mathrm{pH}_{\text {in }}$ was alkalinized to 7.8 within $3 \mathrm{~min}$ of addition of $\mathrm{K}^{+}$and then slightly acidified to a $\mathrm{pH}_{\text {in }}$ of 7.6. When $\mathrm{Na}^{+}$-loaded cells were suspended in medium of $\mathrm{pH} 9.0$, the $\mathrm{pH}_{\text {in }}$ was maintained at about 7.8; upon addition of $\mathrm{K}^{+}$, the $\mathrm{pH}_{\text {in }}$ immediately changed to 8.3 and then gradually decreased to $7 \cdot 8$. These results indicated that the $\mathrm{K}^{+}$uptake induces alkalinization of the cell interior over the $\mathrm{pH}_{\text {out }}$ range 6.0-9.0, and that the $\mathrm{pH}_{\mathrm{in}}$ is regulated by an acidification mechanism. Similar results have been reported for $E$. coli (Kroll \& Booth, 1983).

\section{Generation of inside acidic $\Delta p H$ by the $\mathrm{Na}^{+} / \mathrm{H}^{+}$antiporter}

To examine the generation of inside acidic $\Delta \mathrm{pH}$ by $\mathrm{Na}^{+-}$ loaded cells at $\mathrm{pH}_{\text {out }}$ above $7 \cdot 0$, the $\Delta \mathrm{pH}$ was disrupted by addition of diethanolamine and changes in cellular $\mathrm{Na}^{+}$ and $\mathrm{pH}_{\mathrm{in}}$ were then measured. As shown in Fig. 3, cellular $\mathrm{Na}^{+}$was extruded against its chemical gradient

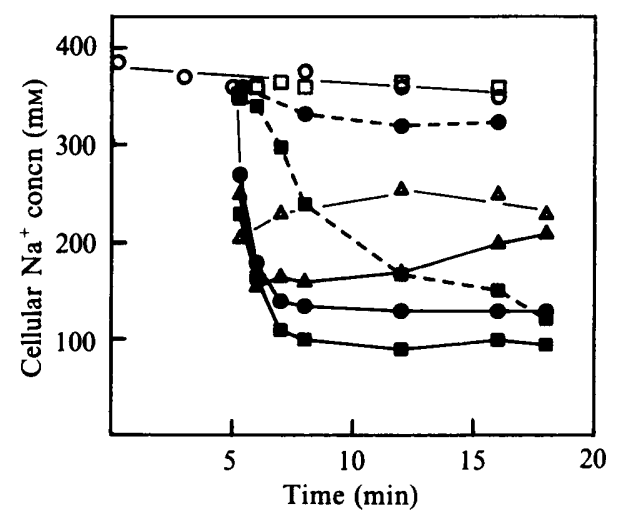

Fig. 3. Effects of diethanolamine on the extrusion of $\mathrm{Na}^{+}$at different $\mathrm{pH}_{\text {out }}$ values. The $\mathrm{Na}^{+}$-loaded cells were suspended in a reaction mixture containing $0.4 \mathrm{M}-\mathrm{NaCl}, 20 \mathrm{~mm}$-glycerol and $4 \mathrm{mM}$-HEPES/ $\mathrm{NaOH}$ (pH 6.6) and pre-incubated for $5 \mathrm{~min}$ at $25^{\circ} \mathrm{C}(\mathrm{O})$. After $5 \mathrm{~min}$, $40 \mathrm{~mm}$-diethanolamine was added so as to adjust the $\mathrm{pH}$ of the medium to $7.0(\square), 7.5(\triangle), 8.0(\triangle), 8.5(\square)$ or $9.0(\bigcirc)$. At various times, cellular $\mathrm{Na}^{+}$was determined by a filtration method $(-)$. For inhibitor experiments, the cells were pre-incubated for $5 \mathrm{~min}$ in the presence of $10 \mathrm{~mm}-\mathrm{KCN}\left(\mathrm{O}^{--}\right)$or $50 \mu \mathrm{M}-\mathrm{HQNO}(\square--\square)$; diethanolamine was then added to adjust the $\mathrm{pH}$ to 9.0 and the cellular $\mathrm{Na}^{-}$determined (---).

at $\mathrm{pH}_{\text {out }}$ values of 7.5-9.0 after addition of $40 \mathrm{~mm}$ diethanolamine, and the extent of $\mathrm{Na}^{+}$efflux varied with $\mathrm{pH}_{\text {out }}$. For example, at $\mathrm{pH}_{\text {out }}$ values of 7.5, 8.0, 8.5 and $9 \cdot 0$, the amounts of $\mathrm{Na}^{+}$extruded 7 min after addition of diethanolamine corresponded to $96,182,274$ and $222 \mathrm{mM}$, respectively, and the $\mathrm{pH}_{\mathrm{in}}$ was determined to be $7 \cdot 1,7 \cdot 1,7 \cdot 5$ and $7 \cdot 8$, respectively. These $\mathrm{pH}_{\text {in }}$ values were identical to those before addition of diethanolamine. Thus, the inside acidic $\Delta \mathrm{pH}$, disrupted by addition of diethanolamine, was regenerated by the extrusion of $\mathrm{Na}^{+}$and the $\mathrm{pH}_{\text {in }}$ returned to the respective original value within $7 \mathrm{~min}$. Since diethanolamine distributes between the inside and outside of cells according to the magnitude of the inside acidic $\Delta \mathrm{pH}$, the amount of diethanolamine within the cells was calculated at the respective $\mathrm{pH}_{\text {out }}$. This value coincided with the amount of $\mathrm{Na}^{+}$extruded at the respective $\mathrm{pH}_{\text {out }}$. Thus, diethanolamine acted as a counter-cation for the $\mathrm{Na}^{+}$extruded. At a $\mathrm{pH}_{\text {out }}$ of 7.0, $\mathrm{Na}^{+}$was not extruded from the cells by addition of diethanolamine due to the absence of an inside acidic $\triangle \mathrm{pH}$. The $\mathrm{Na}^{+}$extrusion observed here was inhibited by $10 \mathrm{mM}-\mathrm{KCN}$, but $50 \mu \mathrm{M}-\mathrm{HQNO}$ (2-heptyl4-hydroxylquinoline- $N$-oxide) which is a specific inhibitor of the $\mathrm{Na}^{+}$pump (Tokuda \& Unemoto, 1984), only delayed $\mathrm{Na}^{+}$extrusion (Fig. 3). These results indicated that $\mathrm{Na}^{+}$extrusion and the generation of an inside acidic $\Delta \mathrm{pH}$ are apparently mediated by the functioning of the $\mathrm{Na}^{+} / \mathrm{H}^{+}$antiporter, which is driven by a protonmotive force, $\Delta \mathrm{P}$. However, it should be emphasized that the $\mathrm{pH}_{\text {in }}$ maintained by the $\mathrm{Na}^{+} / \mathrm{H}^{+}$antiporter at alkaline 


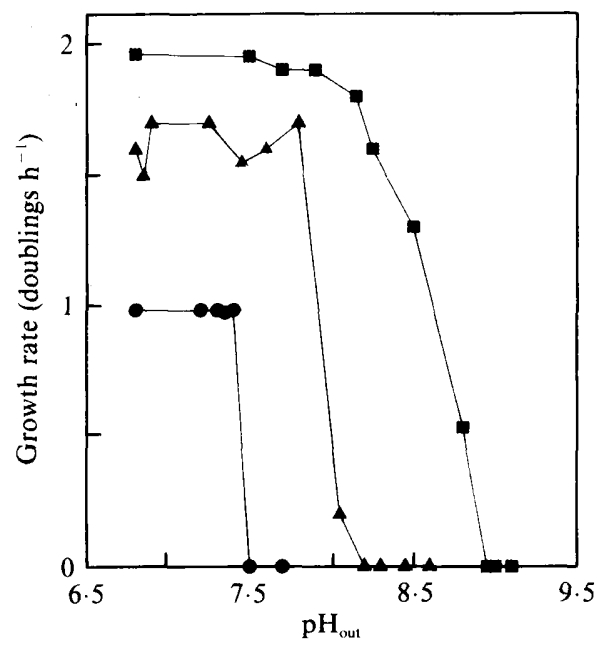

Fig. 4. Effects of $\mathrm{Na}^{+}$and $\mathrm{pH}_{\text {out }}$ on the growth rate of cells in complex medium containing $0.5 \mathrm{M}-\mathrm{KCl}$ and $5 \mathrm{~mm}-(O), 15 \mathrm{~mm}-(\Delta)$ and $50 \mathrm{~mm}$ (Ш) $\mathrm{Na}^{+}$at various $\mathrm{pH}_{\text {out }}$ values. Medium $\mathrm{pH}$ and $\mathrm{Na}^{+}$concentration were adjusted as described in Methods. Growth rate was calculated from the exponential phase of the growth curve and is expressed as the number of doublings $\mathbf{h}^{-1}$.

$\mathrm{pH}_{\text {out }}$ varies with $\mathrm{pH}_{\text {out }}$ and the addition of $\mathrm{K}^{+}$is indispensable to the maintenance of a constant $\mathrm{pH}_{\mathrm{in}}$.

Effect of $\mathrm{Na}^{+}$on cell growth at alkaline $\mathrm{pH}_{\text {out }}$ in the presence of a high concentration of $\mathrm{K}^{+}$

Since the presence of high concentrations of $\mathrm{K}^{+}$disrupts $\mathrm{pH}$ homeostasis at alkaline $\mathrm{pH}_{\text {out }}$ (Fig. 1) and since the $\mathrm{Na}^{+} / \mathrm{H}^{+}$antiporter acidifies the cell interior, the effect of $\mathrm{Na}^{+}$on cell growth in the presence of $0.5 \mathrm{M}-\mathrm{K}^{+}$was examined. The marine $V$. alginolyticus is unable to grow in the absence of $\mathrm{Na}^{+}$. As shown in Fig. 4, growth was supported in the presence of $5 \mathrm{mM}-\mathrm{Na}^{+}$at $\mathrm{pH}_{\text {out }}$ values below 7.5. The inability of the cells to grow at a $\mathrm{pH}_{\text {out }}$ above 7.5 may be related to the difficulty in regulating $\mathrm{pH}_{\text {in }}$ under these conditions (see Fig. 1). Interestingly, an increase in $\mathrm{Na}^{+}$concentration allowed the cells to grow at more alkaline $\mathrm{pH}_{\text {out }}$ values. For example, in the presence of 15 and $50 \mathrm{mM}-\mathrm{Na}^{+}$, cells grew at $\mathrm{pH}_{\text {out }}$ values up to $8 \cdot 1$ and $8 \cdot 8$, respectively (Fig. 4). Precultured cells inoculated into fresh medium containing a high $\mathrm{K}^{+}$ concentration were unable to grow immediately after the transfer, especially at alkaline $\mathrm{pH}_{\text {out }}$, and the length of the lag phase increased with the increase in medium $\mathrm{pH}$. The lag phases were shortened by increasing the concentration of $\mathrm{Na}^{+}$in the medium.

For acidification of the cell interior by the $\mathrm{Na}^{+} / \mathrm{H}^{+}$ antiporter, the externally added $\mathrm{Na}^{+}$must previously be transferred into the cells. Fig. 5 shows the effect of internal $\mathrm{Na}^{+}$on cell growth in the complex medium

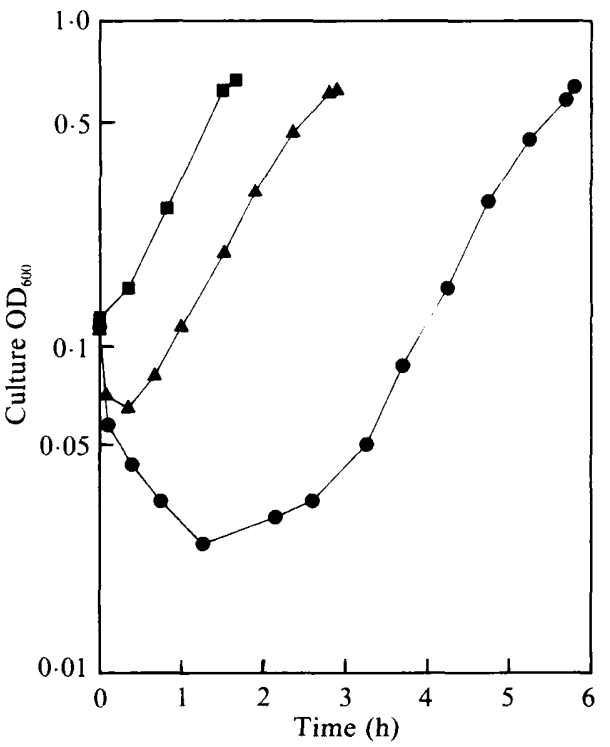

Fig. 5. Effects of cellular $\mathrm{Na}^{+}$on adaptation to complex medium containing $0.4 \mathrm{M}-\mathrm{KCl}$ and $55 \mathrm{mM}-\mathrm{Na}^{+}$at $\mathrm{pH} 8.8$. The cells were precultured in complex medium containing either $0.4 \mathrm{M}-\mathrm{NaCl}(\boldsymbol{\Lambda})$ or $0.4 \mathrm{M}-\mathrm{KCl}(\bigcirc)$ at $\mathrm{pH} 6.8$. Each preculture was diluted 8-fold with fresh complex medium containing $0.4 \mathrm{M}-\mathrm{KCl}$ at $\mathrm{pH} 8.8$. The final $\mathrm{Na}^{+}$ concentration was adjusted to $55 \mathrm{mM}$. In one experiment $(\square)$, the cells were precultured in complex medium containing $0.4 \mathrm{M}-\mathrm{KCl}$ and $55 \mathrm{mM}$ -

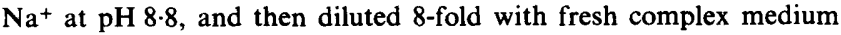
containing $0.4 \mathrm{M}-\mathrm{KCl}$ at $\mathrm{pH} 6.8$.

containing $0.4 \mathrm{M}-\mathrm{KCl}$ and $55 \mathrm{mM}-\mathrm{NaCl}$ at $\mathrm{pH} 8 \cdot 8$. As was expected, cells containing $70 \mathrm{mM}-\mathrm{Na}^{+}$were able to grow after a short lag phase, whereas cells containing less than $5 \mathrm{~mm}-\mathrm{Na}^{+}$required a long lag phase before growth. In the latter case, a significant decrease in optical density of the culture was observed during the lag phase, which was confirmed to be partly caused by cell death. Since the transfer of cells growing in medium of high $\mathrm{K}^{+}$ concentration from $\mathrm{pH}_{\text {out }} 8.8$ to $\mathrm{pH}_{\text {out }} 6.8$ resulted in no lag phase (Fig. 5), the lag phase observed here was apparently related to the regulation of $\mathrm{pH}_{\mathrm{in}}$. Thus, cells seem to be fragile in medium of high $\mathrm{K}^{+}$concentration at alkaline $\mathrm{pH}$ under conditions where the cell interior was not acidified.

The $\mathrm{pH}_{\text {in }}$ of exponentially growing cells in the presence of $0.4 \mathrm{M}-\mathrm{KCl}$ and $55 \mathrm{~mm}-\mathrm{NaCl}$ at $\mathrm{pH} 8.8$ was maintained at about 7.5-7.7 (data not shown). Thus, the inside acidic $\Delta \mathrm{pH}$ was maintained in the growing cells indicating that the $\mathrm{pH}_{\text {in }}$ was not strictly regulated.

\section{Discussion}

The present results clearly indicate that the $\mathrm{K}^{+}$requirement for $\mathrm{pH}$ homeostasis is not identical at acidic and 
alkaline $\mathrm{pH}_{\text {out }}$. At alkaline $\mathrm{pH}_{\text {out }}$ the presence of an outwardly directed $\Delta \mathrm{pK}$ is indispensable, but the addition of $\mathrm{K}^{+}$to the external medium is not necessary for regulation of $\mathrm{pH}_{\text {in }}$ (Fig. 1). This means that the $\Delta \mathrm{pK}$ is required for the generation of an inside acidic $\Delta \mathrm{pH}$. Since the electroneutral $\mathrm{K}^{+} / \mathrm{H}^{+}$antiporter converts $\Delta \mathrm{pK}$ to $\Delta \mathrm{pH}$ until the $\mathrm{pH}_{\mathrm{in}}$ becomes about 7.8 and then ceases to function at $\mathrm{pH}_{\text {in }}$ below 7.6 (Nakamura et al., 1984), the $\Delta \mathrm{pK}$ is apparently utilized as the driving force for the $\mathrm{K}^{+} / \mathrm{H}^{+}$antiporter to maintain $\mathrm{pH}_{\text {in }}$ at about $7 \cdot 6-7 \cdot 8$. Indeed, $\Delta \mathrm{pK}$ is the only effective driving force, especially at alkaline $\mathrm{pH}_{\text {out }}$.

Conversely, at acidic $\mathrm{pH}_{\text {out }}$ the addition of $\mathrm{K}^{+}$to the external medium is indispensable, even in the presence of a large magnitude of $\Delta \mathrm{pK}$ (Fig. 1). The uptake of $\mathrm{K}^{+}$ allows more $\mathrm{H}^{+}$to be extruded by the primary $\mathrm{H}^{+}$pumps and thus alkalinizes the cell interior (Fig. 2). The $\mathrm{K}^{+} / \mathrm{H}^{+}$ antiporter is active at $\mathrm{pH}_{\text {in }}$ values above 7.6; thus it may be driven by the inwardly directed $\mathrm{H}^{+}$gradient when the $\mathrm{pH}_{\mathrm{in}}$ is alkalinized above 7.6 at acidic $\mathrm{pH}_{\text {out }}$, even in the absence of a $\Delta \mathrm{pK}$. The $\mathrm{K}^{+} / \mathrm{H}^{+}$antiporter may regulate $\mathrm{pH}_{\text {in }}$ even at acidic $\mathrm{pH}_{\text {out }}$. The difference in the $\mathrm{K}^{+}$ requirement for the $\mathrm{pH}$ homeostasis observed at acidic and alkaline $\mathrm{pH}_{\text {out }}$ can be explained by postulating the $\mathrm{K}^{+} / \mathrm{H}^{+}$antiporter functions as the regulator of $\mathrm{pH}_{\text {in }}$ over the $\mathrm{pH}_{\text {out }}$ range $6 \cdot 0-9 \cdot 0$.

The $\mathrm{Na}^{+} / \mathrm{H}^{+}$antiporter is also capable of acidifying the cell interior. Castle et al. $(1986 a, b)$ studied the coupling between $\Delta \mathrm{pNa}$ and inside alkaline $\Delta \mathrm{pH}$ in respiring $E$. coli and concluded that the magnitude of $\Delta \mathrm{pNa}$ is determined by the magnitude of $\Delta \mathrm{pH}$ at $\mathrm{pH}_{\text {out }}$ below $7 \cdot 2$. Thus, the $\mathrm{Na}^{+} / \mathrm{H}^{+}$antiporter is mainly driven by the inside alkaline $\Delta \mathrm{pH}$ generated as a result of $\mathrm{pH}$ homeostasis. At alkaline $\mathrm{pH}_{\text {out }}$, since the direction of $\Delta \mathrm{pH}$ is reversed, the inside acidic $\Delta \mathrm{pH}$ is no longer effective as a driving force for $\mathrm{Na}^{+}$extrusion and an electrogenic $\mathrm{Na}^{+} / \mathrm{H}^{+}$antiporter is generally considered to be driven by the protonmotive force, $\Delta \mathrm{P}$. Nakamura $e t$ al. (1984) showed that the generation of an inside acidic $\Delta \mathrm{pH}$ by $\mathrm{Na}^{+}$-loaded cells at $\mathrm{pH}_{\text {out }}$ above 7.0 may be due to the homeostasis of $\Delta \mathrm{P}$ at the respective $\mathrm{pH}_{\text {out }}$. When collapsed by the addition of diethanolamine, the inside acidic $\Delta \mathrm{pH}$ of $\mathrm{Na}^{+}$-loaded cells returns to the respective original value concomitant with the extrusion of $\mathrm{Na}^{+}$ (Fig. 3), clearly indicating that acidification of the cell interior is mediated by an electrogenic $\mathrm{Na}^{+} / \mathrm{H}^{+}$antiporter. In $E$. coli, the $\mathrm{Na}^{+} / \mathrm{H}^{+}$antiporter has been shown to function at $\mathrm{pH}_{\text {in }}$ values above 6.5-7.0 (Bassilana et al., 1984a, b; Nakamura et al., 1986; Taglicht et al., 1991). These properties are suited to the extrusion of $\mathrm{Na}^{+}$over a wide $\mathrm{pH}_{\text {out }}$ range in response to $\Delta \mathrm{P}$.

In medium of high $\mathrm{K}^{+}$concentration, where the regulation of $\mathrm{pH}_{\mathrm{in}}$ by the $\mathrm{K}^{+} / \mathrm{H}^{+}$antiporter becomes difficult at alkaline $\mathrm{pH}_{\text {out }}$ due to the decrease in $\Delta \mathrm{pK}$, cell growth is supported by addition of $\mathrm{Na}^{+}$, even at alkaline $\mathrm{pH}_{\text {out }}$ (Fig. 4). In this case, cells containing higher internal $\mathrm{Na}^{+}$concentrations are able to adapt more easily to these growth conditions (Fig. 5). Moreover, the $\mathrm{pH}_{\text {in }}$ of such cells is acidified. The role of $\mathrm{Na}^{+}$in cell growth at alkaline $\mathrm{pH}_{\text {out }}$ is apparently related to the acidification of the cell interior through the electrogenic $\mathrm{Na}^{+} / \mathrm{H}^{+}$ antiporter. $\mathrm{Na}^{+}$is required for the growth of $E$. coli especially at alkaline $\mathrm{pH}_{\text {out }}$ (McMorrow et al., 1989).

The presence of a $\mathrm{K}^{+} / \mathrm{H}^{+}$antiporter similar to that of $V$. alginolyticus has been reported in Nitrosomonas europaea and Nitrosobactor agilis (Kumar \& Nicholas, 1984), and in the green alga Chlorella fusca (Tromballa, 1987). An ATP-driven $\mathrm{K}^{+} / \mathrm{H}^{+}$antiporter that expels $\mathrm{K}^{+}$ by exchange for $\mathrm{H}^{+}$and is active only at alkaline $\mathrm{pH}_{\text {in }}$ was reported in Streptococcus faecalis (Kakinuma \& Igarashi, 1988). In $E$. coli, two kinds of $\mathrm{K}^{+}$efflux system (kef $B$ and $C$, formerly named $\operatorname{trk} B$ and $C$ ) have been cloned (Munro et al., 1991). Although Kef B and KefC were shown to function as a $\mathrm{K}^{+} / \mathrm{H}^{+}$antiporter, a third system named KefA was considered to function as the regulator of $\mathrm{pH}_{\text {in }}$ (Booth et al., 1985; Douglas et al., 1991). Therefore, it is necessary to further define a true $\mathrm{pH}_{\text {in }}$ regulator among these multiple $\mathrm{K}^{+} / \mathrm{H}^{+}$antiporters.

\section{References}

Bassilana, M., Damiano, E. \& Leblanc, G. (1984a). Relationships between the $\mathrm{Na}^{+} / \mathrm{H}^{+}$antiport activity and the components of the electrochemical proton gradient in Escherichia coli membrane vesicles. Biochemistry 23, 1015-1022.

Bassillana, M., Damiano, E. \& Leblanc, G. (1984b). Kinetic properties of $\mathrm{Na}^{+} / \mathrm{H}^{+}$antiport in Escherichia coli membrane vesicles: effects of imposed electrical potential, proton gradient, and internal pH. Biochemistry 23, 5288-5294.

BoOTH, I. R. (1985). Regulation of cytoplasmic pH in bacteria. Microbiological Reviews 49, 359-378.

Booth, I. R., EPstein, W., Giffard, P. M. \& Rowland, G. C. (1985). Roles of the $t r k B$ and $t r k C$ gene products of Escherichia coli in potassium transport. Biochimie 67, 83-90.

Brey, R. N., Rosen, B. P. \& Sorensen, E. N. (1980). Cation/proton antiport in Escherichia coli. Journal of Biological Chemistry 255, 3944.

Castle, A. M., Macnab, R. M. \& Shulman, R. G. (1986a). Measurement of intracellular sodium concentration and sodium transport in Escherichia coli by ${ }^{23} \mathrm{Na}$ nuclear magnetic resonance. Journal of Biological Chemistry 261, 3288-3294.

Castle, A. M., Macnab, R. M. \& Shulman, R. G. (1986b). Coupling between the sodium and proton gradients in respiring Escherichia coli cells measured by ${ }^{23} \mathrm{Na}$ and ${ }^{31} \mathrm{P}$ nuclear magnetic resonance. Journal of Biological Chemistry 261, 7797-7806.

Douglas, R. M., Roberts, J. A., Munro, A. W., Richie, G. Y., Lamb, A. J. \& BoOTH, I. R. (1991). The distribution of homologues of the Escherichia coli $\mathrm{KefC} \mathrm{K}^{+}$-efflux system in other bacterial species. Journal of General Microbiology 137, 1999-2005.

Garcia, M. L., Guffanti, A. A. \& KRUlwich, T. A. (1983). Characterization of the $\mathrm{Na}^{+} / \mathrm{H}^{+}$antiporter of alkalophilic bacilli in vivo: $\Delta \psi$-dependent ${ }^{22} \mathrm{Na}^{+}$efflux from whole cells. Journal of Bacteriology 156, 1151-1157.

Goldberg, E. B., Arbel, T., Chen, J., Karpel, R., Mackie, G. A., Schuldiner, S. \& Padan, E. (1987). Characterization of a $\mathrm{Na}^{+} / \mathrm{H}^{+}$ 
antiporter gene of Escherichia coli. Proceedings of the National Academy of Sciences of the United States of America 84, 26152619.

IshiKaWA, T., Hama, H., TsudA, M. \& TsUchIYA, T. (1987). Isolation and properties of a mutant of Escherichia coli possessing defective $\mathrm{Na}^{+} / \mathrm{H}^{+}$antiporter. Journal of Biological Chemistry 262, 74437446.

Ivey, D. M., Guffanti, A. A., Bossewitch, J. S., Padan, E. \& KRULWICH, T. A. (1991). Molecular cloning and sequencing of a gene from alkaliphilic Bacillus firmus OF4 that functionally complements an Escherichia coli strain carrying a deletion in the nhaA $\mathrm{Na}^{+} / \mathrm{H}^{+}$antiporter gene. Journal of Biological Chemistry 266, 23483-23489.

Kakinuma, Y. \& Igarashi, K. (1988). Active potassium extrusion regulated by intracellular pH in Streptococcus faecalis. Journal of Biological Chemistry 263, 14166-14170.

Karpel, R., Olami, Y., Taglicht, D., Schuldiner, S. \& Padan, E. (1988). Sequencing of the gene ant which affects the $\mathrm{Na}^{+} / \mathrm{H}^{+}$ antiporter activity in Escherichia coli. Journal of Biological Chemistry 263, 10408-10414.

KROLL, R. G. \& Booth, I. R. (1983). The relationship between intracellular $\mathrm{pH}$, the $\mathrm{pH}$ gradient and potassium transport in Escherichia coli. Biochemical Journal 216, 709-716.

KumaR, S. \& Nicholas, D. J. D. (1984). $\mathrm{Na}^{+}$and $\mathrm{K}^{+}$transport in Nitrosomonas europaea and Nitrosobactor agilis. Biochimica et Biophysica Acta 765, 268-274.

McMorrow, I., Shuman, H. A., Sze, D., Wilson, D. M. \& Wilson, T. H. (1989). Sodium/proton antiport is required for growth of Escherichia coli at alkaline pH. Biochimica et Biophysica Acta 981, 2126.

Mandel, K. G., Guffanti, A. A. \& Krulwich, T. A. (1980). Monovalent cation/proton antiporters in membrane vesicles from Bacillus alcalophilus. Journal of Biological Chemistry 255, 73917396.

Munro, A., Ritchie, G. Y., Lamb, A. J., Douglas, R. M. \& Booth, I. R. (1991). The cloning and DNA sequence of the gene for the glutathione-regulated potassium efflux system KefC of Escherichia coli. Molecular Microbiology 5, 607-616.
Nakamura, T., Hsu, C.-M. \& Rosen, B. P. (1986). Cation/proton antiport systems in Escherichia coli: solubilization and reconstitution of $\Delta \mathrm{pH}$-driven sodium/proton and calcium/proton antiporters. Journal of Biological Chemistry 261, 678-683.

Nakamura, T., TOKUda, H. \& Unemoto, T. (1982). Effects of pH and monovalent cations on the potassium ion exit from the marine bacterium, Vibrio alginolyticus, and the manipulation of cellular cation contents. Biochimica et Biophysica Acta 692, 386-396.

NAKAMURA, T., TOKUDA, H. \& UNEMOTO, T. (1984). $\mathrm{K}^{+} / \mathrm{H}^{+}$antiporter functions as a regulator of cytoplasmic $\mathrm{pH}$ in a marine bacterium, Vibrio alginolyticus. Biochimica et Biophysica Acta 776, 330-336.

Nirya, S., Yamasaki, K., Wilson, T. H. \& TsuchiYa, T. (1982). Altered cation coupling to melibiose transport in mutants of Escherichia coli. Journal of Biological Chemistry 257, 8902-8906.

Padan, E., Maisler, N., TAGlicht, D., KarPel, R. \& Schuldiner, S. (1989). Deletion of ant in Escherichia coli reveals its function in adaptation to high salinity and an alternative $\mathrm{Na}^{+} / \mathrm{H}^{+}$antiporter system(s). Journal of Biological Chemistry 256, 20297-20302.

Slonczewski, J. L., Rosen, B. P., Alger, J. R. \& Macnab, R. M. (1981). pH homeostasis in Escherichia coli: measurement by nuclear magnetic resonance of methylphosphate and phosphate. Proceeding of the National Academy of Sciences of the United States of America 78, 6271-6275.

Taglicht, D., Padan, E. \& Schuldiner, S. (1991). Overproduction and purification of a functional $\mathrm{Na}^{+} / \mathrm{H}^{+}$antiporter coded by nhaA (ant) from Escherichia coli. Journal of Biological Chemistry 266, 11289-11294.

ToxudA, H. \& UNEmoto, T. (1984). $\mathrm{Na}^{+}$is translocated at NADH : quinone oxidoreductase segment in the respiratory chain of Vibrio alginolyticus. Journal of Biological Chemistry 259, 77857790.

Tokuda, H., Nakamura, T. \& Unemoto, T. (1981). Potassium ion is a requirement for the generation of $\mathrm{pH}$-dependent membrane potential and $\Delta \mathrm{pH}$ by the marine bacterium Vibrio alginolyticus. Biochemistry 20, 4198-4203.

Tromballa, H.-W. (1987). Base uptake, $\mathrm{K}^{+}$transport and intracellular $\mathrm{pH}$ regulation by the green alga Chlorella fusca. Biochimica et Biophysica Acta 904, 216-226. 